Northwestern University School of Law Northwestern University School of Law Scholarly Commons

Faculty Working Papers

2010

\title{
The Theory and Practice of Taxing Difference
}

Nancy Staudt

Northwestern University School of Law, n-staudt@law.northwestern.edu

\section{Repository Citation}

Staudt, Nancy, "The Theory and Practice of Taxing Difference" (2010). Faculty Working Papers. Paper 58.

http://scholarlycommons.law.northwestern.edu/facultyworkingpapers/58

This Article is brought to you for free and open access by Northwestern University School of Law Scholarly Commons. It has been accepted for inclusion in Faculty Working Papers by an authorized administrator of Northwestern University School of Law Scholarly Commons. 


\section{HEINONLINE}

Citation: 65 U. Chi. L. Rev. 6531998

Content downloaded/printed from

HeinOnline (http://heinonline.org)

Tue Jun 29 16:27:40 2010

-- Your use of this HeinOnline PDF indicates your acceptance of HeinOnline's Terms and Conditions of the license agreement available at http://heinonline.org/HOL/License

-- The search text of this PDF is generated from uncorrected OCR text.

-- To obtain permission to use this article beyond the scope of your HeinOnline license, please use:

https://www.copyright.com/ccc/basicSearch.do?

\&operation $=$ go\&search $T y p e=0$

\&lastSearch $=$ simple\&all=on\&titleOrStdNo=0041-9494 


\title{
REVIEW
}

\section{The Theory and Practice of Taxing Difference}

\author{
Nancy C. Staudt $\dagger$
}

Taxing Women. Edward J. McCaffery. The University of Chicago Press, 1997. Pp vii, 310.

Edward McCaffery's important new book, Taxing Women, explores the convergence between economic and feminist theory in the tax context. McCaffery argues that feminist and economic theorists who carefully consider the existing tax structure will object to precisely the same pohicies and programs (although on different grounds), and will seek identical tax reform. This is no small claim given the longstanding tension and disagreement that has existed between these two groups, as well as among various individuals within each group separately. Although McCaffery's claim might be shghtly overstated, if he is correct, it certainly suggests that the current tax laws contain serious flaws if scrutinized under a framework either of economic efficiency or gender fairness.

McCaffery begins the book with an exploration of a variety of tax code provisions and tax reform proposals. He not only argues that a number of the provisions and proposals have harmed women, but he also uncovers compelling evidence suggesting that tax theorists and policymakers have purposefully sought to promote a gendered division of labor that pushes men into the market and women into the home. McCaffery claims that this ap-

$\dagger$ Visiting Scholar, Stanford Law School and Stanford Institute on Women and Gender; Associate Professor of Law, SUNY-Buffalo Law School. I would like to thank Guyora Binder, Susan Cahn, and especially Beth Garrett for their help in writing this Review. 
proach to tax policymaking is so entrenched that it continues today with widespread popular and legislative support. Voicing his dislike for this bias in a style that is both witty and poignant, McCaffery notes that the laws are often codified with euphemistic titles such as the "Mother's and Homemaker's Rights Act," which he argnes could more accurately be labeled the "Breadwinning Male Power Act" because it awards tax benefits to the male breadwinner in single earner couples ( $p$ 219). Throughout the book, McCaffery argnes that Congress advances the interests of men with stay-at-home spouses while it impedes married women working in the waged labor force.

After McCaffery's strong argument that the tax laws are unjust from a gender perspective, he turns to the optimal theory of taxation. Pointing to the economic principles underlying this theory and empirical studies that suggest that married women are highly responsive to changes in the tax rate, he argues that Congress could promote efficiency if it taxed married women at a lower rate than men and single women-precisely the opposite of what Congress has done historically. The efficiency rationale for lowering tax rates on women is particularly powerful given McCaffery's conclusion that just such a reform is needed if the tax laws are to be gender neutral. ${ }^{1}$

Although McCaffery provides a detailed and nuanced analysis of the feminist and economic issues, his work is problematic in several ways. First, it is not clear that the optimal theory of taxation leads to the policy reform he proposes-it may be both underinclusive and overinclusive. Second, even if McCaffery has identified a clear economic rationale for taxing married women at a lower rate than men and single women, feminists may object to this proposed tax structure on a number of grounds. Finally, McCaffery's theoretical arguments for tax reform ignore the political problems associated with implementing legal change in the real world. As a number of political theorists have noted, legislators tend to pursue pohicies and programs that advance their own interests even when it entails rejecting public-regarding policy proposals. Despite these shortcomings, however, McCaffery's indepth and interdisciplinary analysis represents an important advance in this area of the law. Taxing Women is a book that will be of interest to a wide range of theorists and pohicymakers.

This Review is organized as follows. Part I describes the argument in Taxing Women. Part $I$ considers the possible coalition

1 McCaffery argues that the "ostensibly neutral, objective, quasi-scientific economic theory precisely agrees with the long-standing feminist critique of the tax laws" ( $p 169$ ). 
that will form around McCaffery's proposed tax reform. Although it is clear that a number of feminists and efficiency theorists will support the proposal, universal support from both groups is impossible given the disagreements that exist between the two groups and among the members of each individual group. Part III then argues that even if feminist and economist theorists could reach consensus on a specific tax reform proposal, such a coalition would not guarantee the proposal's implementation. Congressional members are unlikely to pursue legislation-although efficient and fair-if such legislation interferes with the symbohic message they seek to convey to voters.

\section{THE ARGUMENT IN TAXING WOMEN}

\section{A. Historical and Contemporary Political Struggles in the Tax Context}

McCaffery devotes a significant portion of Taxing Women to the pohtical struggles that have taken place around the development of the family tax rules. Parts I and II of the book investigate a predictable list of policies and provisions-including the joint return provisions, Social Security laws, fringe benefit rules, and the nontaxation of imputed income-all of which have been extensively explored and criticized in the tax and feminist hiterature before. The book, however, does not leave the reader disappointed. McCaffery's nuanced analysis of the political and intellectual history of the code produces a number of new and important insights. Moreover, Part III of the book considers contemporary tax pohicy proposals, largely ignored in the hiterature, enabling McCaffery to demonstrate that his arguments addressing gender equity and market efficiency are of more than histerical interest.

Consider McCaffery's analysis of the development of the joint return provisions. He begins with the standard description of Congress's decision to move from an individual to a joint filing system, but comphicates the story by highlighting the pohtical tradeoffs associated with the various joint reform proposals. As McCaffery points out, the controversy around the issue initially arose because, in 1913, Congress adopted progressive marginal tax rates along with mandatory individual filing ( $p p$ 29-34). As a number of tax and economic theorists pointed out, these dual policies produced a tax burden that varied with the wife's decision to work rather than with the level of family income. For example, a couple with each spouse earning $\$ 15,000$ in the waged labor market would be subject to a lower marginal tax rate than 
a single wage earner earning $\$ 30,000$ of incoine. This, of course, encouraged single earner couples to establish unarital agreements and family business arrangements that divided income and property between the two spouses in order to reduce their tax burden to the level of dual earning couples ( $\mathrm{pp}$ 35-42). The 1913 tax code, therefore, raised two distinct problems: it violated the principle of horizontal fairness, which mandates that equal earning couples be taxed at equal rates, and it served as an incentive for couples to manipulate their tax burdens through income-sphtting arrangements. Accordingly, tax theorists and pohcymakers began to debate the merits of a mandatory joint filing system. As McCaffery points out, this debate took a number of unpredictable twists and turns-largely ignored in the literature but key to understanding the gendered nature of the code.

In moving to a joint filing system in the early 1940 s, Congress had a clioice between raising the level of taxation on dual earning couples or reducing the burden on single earning couples; either option would ensure horizontal equity and eliminate the possibility for couples to manipulato their family finances for tax purposes. The initial 1941 reform proposal contained a rule that required all married couples to pay taxes as if they were a single, unmarried person (pp 49-51). This proposal, in effect, repealed the benefit obtained by couples with both spouses in the waged labor market.

In a surprise move, conservatives and Republicans objected to the proposal, arguing that mandatory joint filing represented problematic social policymaking that would encroach "on the independent status and social, economic, and political individuality of women which has been won only after a long struggle" ( $p 50)^{2}$ In short, the opposition maintained, joint return filing was a "proposal out of the dark ages, [one] which would set the cause of emancipation of women back five lundred years" ( $p 50$ ).

Initially, it seems puzzling that conservative politicians would object to legal reform because the proposed law assumed that married couples operate as a unit rather than as two autonomous individuals. McCaffery, lowever, explains the surprising phenomenon. More important, he demonstrates low politicians and theorists have used the rhetoric of women's rights and responsibilities as a means to legitimate tax provisions that in theory advance women's interests but, in practice, work to maintain women's marginalized status in society.

2 Citing Randolph E. Paul, Taxation in the United States 273 (Little, Brown 1954). 
In discussing the 1941 proposal, McCaffery points out that most married couples had a combined level of income that exempted them from taxation entirely or placed them in the lowest tax bracket under either individual or joint filing ( $p$ 50). Accordingly, the debate over the proposed joint filing regime was of interest only to wealthy families. Moreover, because the 1941 proposal would prevent strategic income-sphtting arrangements, it would tax these families at a higher rate than under the previously existing individual filing system. In response, the high earners, most of whom were men with stay-at-home wives (pp 50-51), sought to defeat the proposal by arguing that a joint filing requirement would harm women's hard-won independent status. But as McCaffery points out, these taxpayers were hardly champions of women's rights; a few years later, they supported a reform proposal with a joint filing requirement that unambiguously harmed women's economic interests. This second proposal, which ultimately prevailed, assumed married couples were a single economic unit, but it also reduced the rates on single earner couples to that of the dual earner couples. Or, in McCaffery's words, the rates were set at "equal to twice what a single person earning half the total family income would pay" ( $p$ 54).

This rule left the tax burden on dual earner couples unchanged, but provided a benefit to single earner couples. Although the outcome initially appears to be the product of a nonzero sum game with regard to taxpayers, if the family is disaggregated it becomes clear that women suffered a significant economic setback. First, the laws eliminated the need to spht income and thus discouraged men from transferring income and property to their wives in order to reduce their own tax hability. The joint return provisions simply allowed a reduction in the tax burden without such a transfer, thereby denying women the legal title to property and income once gained under the individual filing rule. Moreover, the joint return provisions produced the well-known "stacking effect," which essentially mandated that secondary wage earners (or married women earning less than their husbands in the waged labor force) pay taxes at their husbands' highest marginal tax rate. ${ }^{3}$ The joint return provisions,

3 Because the joint return provisions require that couples aggregate their income, the second wage is "stacked" on top of the first wage. Such stacking in effect subjects the secondary wage earner to the highest marginal tax rate of the primary wage earner rather than to the lower-or even zero-rate available if the spouses filed separately. See Nancy C. Staudt, Taxing Housework, 84 Georgetewn L J 1571, 1606-10 (1996) (discussing the economic impact of joint return filing on dual earner couples). Many theorists argue that this effect imposes costs on women because their waged work is often viewed as less important te the family and because women tend to make work decisions (including the de- 
therefore, harmed married women regardless of whether they worked in or out of the home. ${ }^{4}$ In short, the earher arguments about women's rights were simply pohtical means for defeating a pohicy proposal that raised taxes on working men with stay-athome wives. Women's status as full and equal citizens was of httle or no importance to those who objected to the initial joint return proposal.

The political struggle that produced the joint return provisions was not an isolated incident where congressional members raised concerns for women's rights while simultaneously adopting policies that imposed harm. McCaffery argues that the Social Security provisions also have a negative effect upon women. These laws enable married women to receive retirement benefits without ever having to work outside the home. Congress arguably adopted this policy in recognition of women's unpaid contribution to the family and the corresponding economic insecurity that comes with unpaid labor ( $p$ 95). While the Social Security laws clearly offer protection to married women who are economically dependent, they have a number of pitfalls that limit the number of women who have access to such protection. In order to obtain the benefits, for example, women must be married for ten years or more ( $p$ 97). Today, however, the average length of marriage before divorce is seven years ( $p$ 97). Because most individuals do not anticipate a divorce at the time of marriage, women enter marriage expecting, despite this statistic, that the law will provide them with a certain level of econoumc security. Upon divorce, however, women often find themselves living in poverty at the time they would have begun to collect Social Security income if they had stayed married. The rules not only harm stay-athome spouses but also impose costs upon married women in the waged labor force. Because married women will obtain the Social

cision te leave the paid labor force) based, in part, on this higher tax rate (pp 11-23). See also Staudt, 84 Georgetown $L J$ at 1608-10.

4 One could argue that women who did not work in the waged labor force but who were married to high-income wage earners benefited from the reduction in tax rates available under the jomt return provisions. This argument assumes that couples pool their income, an assumption that must to some extent be true in light of the fact that it is next to impossible to prevent a spouse from individually consuming certain family purchases, such as the home. See Lawrence Zelenak, Marriage and the Income Tax, $67 \mathrm{~S} \mathrm{Cal}$ L Rev 339, 351-58 (1994). A more rigorous analysis, however, would suggest that control over purchasing decisions also is relevant to women's well-being. Such control is most likely unavailable te the married woman who does not work in the paid labor force. See Anne L. Alstott, Tax Policy and Feminism: Competing Goals and Institutional Choices, 96 Colum L Rev 2001, 2028 (1996) (noting that both control and consumption are relevant for understanding the complex issues that arise with regard to normative questions concerning intrafamily pooling arrangements). 
Security benefits whether or not they work for a wage, there is no marginal return on the first dollars they pay into the system ( $p$ 95). Indeed, married women will only receive additional benefits from the Social Security taxes they pay if they have a longterm, stable, and high-paying job in the waged labor force-a situation most women are unable to achieve. Thus, although the Social Security laws seem to benefit women, in practice, they actually encourage women to undertake a caretaking role in the home, a role that might harm them in the long run. ${ }^{5}$

In addition to the joint return provisions and the Social Security laws, McCaffery argues that the nontaxation of imputed income, the fringe benefit provisions, and the state tax laws all appear neutral on the surface but, in fact, impose significant costs on women (pp 89-160). ${ }^{6}$ In reading McCaffery's thorough investigation of these various tax provisions, the reader is struck by the level of historical detail the author provides. He investigates a wide range of documents largely pubhshed between 1920 and 1960, including various versions of the federal tax code, state tax laws, legislative histories, court opinions, textbooks, and law review articles, most of which suggest that Congress, the courts, and commentators consciously pursued tax pohicies that encouraged women to work in the home, thereby imposing upon women the costs attached to the caretaking role. At the same time, however, the reader cannot help but wonder if McCaffery simply has identified laws and pohicies that are the product of antiquated social norms estabhshed in the long-gone era of "deep patriarchy." Although McCaffery correctly points out that the provisions and pohicies estabhished decades ago provide an economic disincentive

s Because individuals who move in and out of the waged labor forces are penalized by the Social Security system, women must devote uninterrupted time to paid labor. At the same time, if women are to obtain at least the same level of benefits to which they are entitled as a wife, they must pay the Social Security tax attached to a high wage rate ( $p$ 95). For the inost rigorous discussion of the problems facing women in the Social Security context, see Mary E. Becker, Obscuring the Struggle: Sex Discrimination, Social Security, and Stone, Seidman, and Tushnet's Constitutioual Law, 89 Colum $\longleftarrow$ Rev 264, 276-85 (1986).

- By failing to tax imputed income, Congress encourages women to work in the home rather than the market (pp 120-26). See Staudt, 84 Georgetown $L \mathrm{~J}$ at 1590 (cited in note 3). Moreover, the failure to tax housework implies that women's caretaking responsibilities have no economic value. Finally, nontaxation denies women access to Social Security and Medicare benefits. Id at 1596-99. The tax treatment of fringe benefits and the economic impact upon women has nuch the same effect as the Social Security laws (pp 12832). Indeed, McCaffery argues that even the provisions ostensibly designed to assist women in the waged labor force offer little to no economic assistance. In particular, McCaffery notes that the childcare provisions offer only minor assistance to most working women and no benefits to most poor women because the credits are nonrefundable (pp 106-20). 
for women to work in the market (pp 134-35), empirical data suggest that the laws may have little or no actual impact upon contemporary women. For example, despite the resiliency of these tax laws, the vast majority of women in the late twentieth century do work in the marketplace, and these numbers continue to rise as social mores change. ${ }^{7}$

Although he acknowledges the widespread entry of women into the paid labor market, McCaffery nevertheless points out that popular support for the single earner family continues to exist today. National polls taken over the course of the last twenty years indicate that 62 percent of Americans feel married women should cede their jobs to men when jobs are scarce and 55 percent of those polled think it is more important for women to advance the careers of their liusbands than to have careers of their own (pp 22, 77). Moreover, various groups, such as "Mothers at Home, Inc." continue to lobby Congress for recognition of women's work through economic incentives advantaging two parent, single earner families ( $p$ 119). Finally, legislators frequently take the position that women do not want to work but are forced into the waged labor market to lielp offset the costs of raismg a family (p 210). ${ }^{8}$

The Christian Coalition's Contract with the American Family and the Republican party's Contract with America-botlı products of the 1990s-provide clear evidence that policies and programs advantaging stay-at-home spouses are not mere relics of a past era but are a very real contemporary plienomenon. According to the architects of these documents:

It is hard to overestimate our tax code's damage to American families. Many people look back to the 1950s and the 1960s with nostalgia. At least with regard to the tax code, that nostalgia is understandable. Those were the days when one income was often all that was needed to support a family. Today, many families need two incomes just to pay taxes and meet basic needs (pp 207-08) (empliasis added).

2 See Beth Ann Shelton, Women, Men and Time: Gender Differences in Paid Work 35 (Greenwood 1992) (noting increased participation in the marketplace by women between 1875 and 1984).

${ }^{8}$ As McCaffery explains at $\mathrm{p} 210$, Representative J. Dennis Hastert, a high-ranking Republican, argued that "[m]others are still forced to go inte the workforce, not because they want to but because, economically, if they want to provide for the education of their children ... they have no clroice." Reclaiming the Tax Code for American Families, Hearings Before the Select Committee on Children, Youth, and Families, 102d Cong, 1st Sess 113 (1991) (statement of Representative Hastert). 
In short, the Contracts suggest that women do not want to work, but must work in order to pay federal taxes ( $p 210$ ).

Given this underlying assumption, legislators continue to pursue pohicies that arguably encourage women to remain in the home. The Contracts, for example, propose tax reform that involves a nonrefundable credit of $\$ 500$ per child to each family (pp 213-15). McCaffery argues that this credit will provide a further disincentive to women's market work because: (1) the credit is tied to the number of children in the household rather than to childcare expenses or other market-related activities; and (2) the credit leaves the secondary earner distortions in place. ${ }^{9}$ With the additional $\$ 500$ available, women might feel less need for a market wage and thus nonworkers will choose to remain in the home and secondary wage earners already in the market will be encouraged to substitute household labor for market labor (pp 21417). Indeed, the authors of the Contracts purposefully desigued the credit to have just this behavioral impact. They argue that women are overwhelmed and overtired from working in the home and in the market ( $p$ 208). The credit, therefore, is intended to insert a measure of gender justice into the tax code by enabling women to return to the home. But as McCaffery points out, this is a rather peculiar form of gender justice and at the same time is highly controversial.

The pohtical documents proposing the child credit suggest that women have both the right and the responsibility to undertake the traditional caretaking role. According to McCaffery, this rhetoric simply promotes the long-term economic instability routinely suffered by caretakers. While his claim is accurate in some situations, McCaffery fails to recognize that the child credit may produce behavioral effects unpredicted by authors of the Contracts. ${ }^{10}$ Because the credit is nonrefundable, it may produce just the opposite effect on low-income women than that incurred by high-income women. Nonrefundable credits are available only if the family has a tax burden to offset; with no existing tax burden, the credit is useless. Accordingly, because the credit will reduce the cost of being in the market, poor nonworking women may substitute market labor for household labor. ${ }^{11}$ Moreover, the

These distortions, as noted above, are found in the joint return provisions, the Social Security laws, the fringe benefit provisions, and the decision to leave imputed income untaxed.

${ }^{10}$ For a brief discussion of the actual child credits adopted, see Martin J. McMahon, Jr., The New Child Credits: Explainable Mechanics and Unfathomable Policy, Tax Notes Today Doc 97-26596 (Sept 22, 1997).

"The substitution effect experienced by nonworking women, however, will be teinpered if the women incur a loss of welfare benefits. 
credit may encourage low-income women already employed in the market to increase the number of hours they work up to the point at which they are able to obtain the full benefit of the credit. Once women achieve access to the full credit, however, they will have no incentive to devote more hours to the market. ${ }^{12}$ Indeed, at this point, working women will face an extremely high marginal tax rate, thereby discouraging further market participation. In short, the credit is likely to encourage middle- and upper-income women to undertake the traditional caretaking role, but may have just the opposite effect on low-income women.

This more nuanced analysis suggests that Congress might perceive a woman's role in society as integrally linked with her level of income and not, as McCaffery suggests, simply a function of her sex. ${ }^{13}$ This distinction is important because it imphes that pohcymakers seek to circumscribe women's freedom of choice through a variety of means and for a number of different reasons. Middle- and upper-income women will be encouraged to work in the home while low-income women will be pushed into the market. Any violation of these roles could result in the loss of lucrative tax benefits-a loss many women may not be willing or able to afford.

After critiquing the proposed child credit (albeit on more narrow grounds than I suggest), McCaffery turns to the various flat tax proposals, all of which he argues provide a further example of contomporary pohicymaking that incorporates hidden biases agaimst working married women. He notes that the proposals all contain both a high zero bracket and a joint filing feature. Together, these provisions work to maintain (and potentially exacerbate) the secondary earner bias found in the existing tax systom (pp 220-24). Due'to the "stacking effect," the proposed flat tax will-as under today's system of increasing marginal ratestax the secondary wage earner at her husband's highest rate. If the flat tax included an individual filing component, many women would be free of taxes given the high personal exemptions

${ }^{12}$ Of course, because the proposal does not tie the credit to women's tax burdens, men may experience the income and substitution effects in certain situations.

${ }^{13}$ While McCaffery does not explore the behavioral impact of a nonrefundable child credit on low-income women, he does note that the credit has problematic distributional effects that favor high-income women. For example, the debate around the child credit proposal has centered on whether Congress should phase out the benefit at high-income levels. Under one proposal, the phase-out begins at $\$ 110,000$ and the credit is fully phased out when the family income reacbes $\$ 150,000$. Perversely, under this plan just 5 percent of children would receive less than the full credit because of their upper-income status while 44 percent of children would fail to gain the benefit due to their family's lowincome level ( $\mathrm{p} 215$ ).

"See notes 3-4 and accompanying text. 
and dependency allowances incorporated into the proposals. But, with joint filing, married women working in the waged labor force will again suffer higher tax rates than all other taxpayers earning a similar wage. This high tax rate, in turn, will encourage women to work in the home rather than in the market. Moreover, low-income married women are likely to suffer a greater burden under a flat tax than under the current progressive marginal rate system. This outcome will occur because, in order to finance the flattening of the overall rate structure, Congress will be forced to adopt a flat tax that has a higher rate than today's lowest marginal rate. In short, as McCaffery points out, the flat tax proposal will beneflt the primary wage earner in the household and disadvantage women in general and low-income women in particular. ${ }^{15}$

In discussing the increased exemption levels found in the flat tax proposals, McCaffery points to a surprising development in the political struggle over family taxation. He notes that a coalition of progressives and conservatives has formed around the increased personal exemption and dependency deductions similar te those found in the flat tax. Pat Schroeder, a well-known liberal feminist, and a number of prominent conservatives all support legal reforms that include a large zero bracket ( $p p$ 221-23). While conservative support for this kind of tax reform is unsurprising (given that increased personal exemptions will lower the tax burden on primary wage earners, who are overwhelmingly men), McCaffery argues Schroeder's support is disturbing in light of the fact that the proposal maintains the biases against working women ( $p$ 223).

What Schroeder fails to recognize, according to McCaffery, is the fact that raising the zero bracket las significant opportunity costs. It is a tax reduction that largely benefits men and, due to revenue concerns, eliminates competing tax reform proposals that would work to the advantage of women. In short, McCaffery implies that a more rational feminist position would entail supporting a proposal that called for individual filing along with a smaller zero tax bracket. Schroeder's failure to take this alternative position demonstrates the truly hidden nature of the secondary earner bias ( $p$ 224).

Yet here again, McCaffery can be criticized for his focus on middle- and upper-income women. Schroeder's support for the

${ }^{15}$ The lowest marginal rate is currently 15 percent. The popular flat tax proposals suggest a rate of 17 percent and 19 percent (p 220) (examining the Armey plan and the Hall and Rabushka propesal). 
large zero bracket feature is most likely based on the fact that it will advantage low-income families, perhaps eliminating them entirely from the income tax base. The plan, therefore, has potentially positive distributional effects. McCaffery's alternative proposal (a rate structure with a narrow zero bracket and individual filing) will clearly benefit middle- and upper-income married women, but low-income women will suffer under the plan given that they are more likely to fall within the tax base. The point here is not that McCaffery is wrong with regard to the existence of secondary earner bias, but rather that tax reform proposals must be examined from a variety of perspectives before any conclusion can be drawn and, more important, before they are discarded. Many feminists, for example, would object to a proposal that advantaged middle- and upper-income women while disadvantaging lower-income women.

\section{B. Inefficient Taxation as the Basis for Proposed Reform}

In Part III of Taxing Women, McCaffery turns from gender justice to economic efficiency. He argues that the developments in economic theory over the course of the last thirty years provide a way out of the existing pohicy dilemmas and pohtical struggles discussed in Parts I and II of the book. Specifically, McCaffery points to the optimal theory of taxation, ${ }^{16}$ which prescribes tax rules that minimize the distortion of individual decisions in the free market. ${ }^{17}$ The theory is based on the assumption that, in the absence of taxation, the market will allocate goods in a manner that is both efficient and fair, in the sense that the distribution maximizes utility. ${ }^{18}$ Under the optimal theory of taxation, Congress must set tax rates at inverse proportion to the elasticity of the taxpayer's behavior in order to minimize the welfare loss caused by taxation (pp 179-82). ${ }^{19}$ Thus, inelastic behavior should be taxed at high rates; elastic behavior should be taxed at low rates. This concept is known in economics as the "inverse elasticity" rule.

${ }^{16}$ The optimal theory of taxation grows out of the work of Frank Ramsey and James Mirrlees. See generally F.P. Ramsey, A Contribution to the Theory of Taxation, 37 Econ J 47 (1927); J.A. Mirrlees, An Exploration in the Theory of Optimum Income Taxation, 38 Rev Econ Stud 175 (1971).

${ }^{17}$ See Nancy C. Staudt, The Hidden Costs of the Progressivity Debate, 50 Vand L Rev 919, 929 n 26 (1997) (exploring the surprising relationship between taxation and freemarket principles).

${ }^{18}$ See Harvey S. Resen, Public Finance 319-22 (Irwin 3d ed 1988) (discussing "excess" burdens created by selective taxation).

${ }^{19}$ See id at 322. 
Because empirical studies suggest that married women's labor supply is particularly elastic (that is, it is highly responsive to marginal tax rates), high marginal taxation of married women may give rise to high welfare losses ( $p$ 200). Accordingly, McCaffery proposes that Congress lower the marginal tax rate upon married women, thereby increasing society's aggregate welfare as well as the welfare of individual families. ${ }^{20}$ This result occurs because the gain in wives' welfare attributable to the tax decrease will arguably outweigh the loss in husbands' and single workers' welfare with the general marginal tax increase needed to ensure revenue-neutral reform. ${ }^{21}$ Because optimal tax theorists seek to maximize aggregate utility even at the expense of women's well-being, economic and feminist theory will not always coincide. However, McCaffery points out that in this case the pohcy prescription under both arguments is identical because the tax laws have a disproportionate impact on married women's decision to work in the waged labor force (p 200). ${ }^{22}$

McCaffery's turn to economic theory is key for two reasons. First, he identifies a convergence between feminist and economic thought, an intersection often left unexplored by legal scholars in general and tax scholars in particular. Second, and perhaps more important, McCaffery argues that economic theory is particularly useful for devising tax reform. Implying that arguments addressing fairness and gender justice tend to reflect the interests of the individual reformer while efficiency arguments tend to reflect the interests of society at large, McCaffery argues that economic theory provides an "external grounding . . . something outside the private subjective preferences of any one author, or of any hberal, culturally elite vanguard. It thus deserves a central position in the larger story of taxing women" ( $p$ 168).

While a number of economic theorists might agree with McCaffery's characterization of economics as an objective framework for analyzing legal questions, his use of the optimal tax theory ignores the value judgments that most economists recognize must be factored into tax policymaking. Moreover, it is not at all clear that feminists will unanimously support McCaffery's proposal to decrease the tax rates of married women. I discuss

\footnotetext{
${ }^{20}$ See Alstott, 96 Colum L Rev at 2013 (cited in noto 4).

${ }^{21}$ See id (arguing that efficiency goals might be even better served by reduced marginal rates for married women).

${ }^{22}$ See also Rosen, Public Finance at 337 (citod in note 18) (noting improved efficiency of higher marginal taxation of hushands); Alstott, 96 Colum L Rev at 2013 (cited in note 4) (noting that the efficiency claim is consistont with the claims made by feminists on economic grounds).
} 
the potential objections to McCaffery's use of the optimal tax theory in Part II below. I then turn, in Part III, to the problems associated with implementing the optimal theory of taxation in the current pohtical context.

\section{OBJECTIONS TO MCCAFFERY'S USE OF THE INVERSE ELASTICITY RULE}

\section{A. Economists' Objections}

While McCaffery is correct that efficiency theorists support the inverse elasticity rule, it is not clear that they would support the particular reform that he advocates. McCaffery's reform calls for a decrease in the tax burden on all married women and an increase in the tax rate on all men and single women. Econometric studies, however, suggest that not all married women have an elastic labor supply. Both low-income married women and married women already in the waged labor market, for example, tend to have a relatively inelastic labor supply, perhaps due to a need for income or simply to their desire to work. ${ }^{23}$ Thus, from an efficiency standpoint, McCaffery's proposal is overinclusive: economists would not propose low tax rates on all married women; instead, economists would seek to decrease taxation only upon middle- and upper-income married women who are not currently working in the waged labor force. ${ }^{24}$ Further, econometric studies suggest that McCaffery's plan to decrease taxation of married women is also underinclusive. Data indicate, for example, that elderly individuals, male and female, are highly responsive to changes in the wage rates. ${ }^{25}$ An efficiency theorist, therefore, would suggest that the low tax rate be applied not only to relatively wealthy, nonworking married women but also to elderly individuals. In short, pure efficiency-oriented theorists might reject McCaffery's proposal in hight of the potential welfare losses associated with taxing elastic behavior at high marginal rates and missing revenue opportunities by taxing inelastic behavior at low rates.

${ }^{23}$ See James J. Heckman, What Has Been Learned About Labor Supply in the Past Twenty Years?, 83 Am Econ Rev Papers \& Proceedings 116, 118 (May 1993) (noting the similarities in "hours worked" elasticity between men and women participating in the labor force).

${ }^{24}$ See, for example, Resen, Public Finance at 337 n 8 (cited in note 18) (emphasizing that elasticity, not gender, is the crucial consideration in optimal tax theory).

${ }^{25}$ See Joseph Bankman and Thomas Griffith, Social Welfare and the Rate Structure: A New Look at Progressive Taxation, 75 Cal L Rev 1905, 1927 (1987) (discussing possible reasons for high elasticity observed among the elderly). 
McCaffery might acknowledge these pitfalls but nevertheless argue that efficiency theorists will support his proposal. First, the proposal may be far more efficient than the existing tax regime given that the current laws fail to account for any differential in men's and women's labor supply curves. Second, a more nuanced reform proposal that accounts for the various econometric studies might be rejected on grounds of simplicity. It is widely understood that elaborate legal distinctions create inefficient complexities that, in turn, impose welfare losses upon society. Thus, the underinclusive and overinclusive nature of McCaffery's proposal may be precisely the reason that efficiency-oriented economists support it.

Although McCaffery's proposal may be defensible from a pure efficiency standpoint, it is also important to recognize that most economists are not concerned solely with efficiency. Guided also by fairness concerns, economists have rejected various forms of simple and efficient taxation. For example, the lump sum tax is least likely to produce behavioral distortions and welfare losses and thus should be supported by efficiency-oriented theorists. ${ }^{26}$ Yet, given the extremely regressive impact of a lump sum tax, market-based theorists and policymakers have widely rejected it as a policy option and have turned instead to a system based on income and consumption. ${ }^{27}$ McCaffery's apphication of the inverse elasticity rule would raise fairness problems similar to those encountered with the lump sum tax. The inverse elasticity rule, for example, prescribes high taxes for price inelastic goods such as food and water as well as life saving drugs such as insulin ( $p$ 192).$^{28}$ It would also require imposing high tax burdens on the waged labor of low-income women-one of the most economically vulnerable groups in society, which also happens to have an inelastic labor supply curve. Borrowing the insights of the optimal theory of taxation, therefore, does not eliminate the fairness concerns that McCaffery suggests are so intertwined with private subject preferences. Indeed, as economists routinely note, there are many controversial value judgments that must be addressed if Congress is successfully to implement the optimal tax system. ${ }^{29}$

McCaffery recognizes this problem and readily acknowledges that Congress should not adhere to efficient taxation in all cir-

${ }^{26}$ See Rosen, Public Finance at 306-10 (cited in note 18).

${ }^{27}$ See id at 310.

${ }^{23}$ See id at 335-36.

2 See id at 346; Joseph E. Stiglitz, Economics of the Public Sector 481 (Norton $2 d$ ed 1988). 
cumstances. Indeed, he implies that low-income women should not suffer the high tax burdens that he proposes Congress levy upon men and single women ( $p$ 194). Yet once McCaffery is willing to make sucl an exception to the inverse elasticity rule, lie must identify a principle that dictates when Congress must adliere to the rule and when Congress is free to ignore it. But once he identifies such a principle, he will inevitably lose the support of various economic theorists, many of whom will have a completely different view on the fairness/efficiency tradeoff.

Moreover, acknowledging the importance of fairness challenges McCaffery's earlier claim that optimal tax theory provides neutral principles upon which to base tax reform ( $p$ 168). It suggests that here, as elsewhere, there are no objective principles that will garner universal support. Not only are neutral principles impossible to identify, but the inclination to hide tax politics behind a façade of neutrality may do voters a disservice. This approach to policymaking implies that there are no difficult decisions or tradeoffs and thus denies voters an opportunity to engage in useful debate on the issues at hand.

Althougl McCaffery fails to investigate the difficult issues that arise in the fairness debates, traditionally tax theorists and policymakers lrave considered an individual's "ability to pay" as the appropriate standard for determining fair tax rates. If McCaffery accepts this standard, he must allow for relatively low tax rates on all low-income taxpayers-married, single, male, and female. If all these groups are entitled to low rates for fairness reasons and married women are entitled to low rates for efficiency reasons, then Congress is left taxing middle- and upperiucome men and middle- and upper-income single women at the highest marginal tax rates. The sclieme begins to look identical to the existing progressive marginal tax rate structure witl a special exemption for middle- and higln-income married womenan outcome that progressivity theorists will find objectionable. ${ }^{30}$

Of course, progressivity theorists miglit support McCaffery's proposal if it were better tailored to account for the ability-to-pay norm. For example, Congress conld lower the rates on all mar-

${ }^{30}$ Because the ability-to-pay norm is based on the underlying assumption that income has decreasing marginal utility, the norm suggests no rationale for providing a special exemption for middle- and upper-income married women. Indeed, because these taxpayers are frequently married to higb-income men, McCaffery's proposal is particularly perverse given the likelihood that the family will pool income to some extent. Accordingly, feminist theorists are more likely to take the position that Congress should further reduce the tax rates on low-income women at the cost of raising the ratos on middle- and high-income women, despite the efficiency rationale for decreasing the tax rate on this latter group. 
ried women, including middle- and upper-income married women, and at the same time raise the rates on middle- and upper-income married men, but not on low-income married men or single men and women. This scheme would enable all married women to have the advantage of low marginal rates that would satisfy McCaffery's efficiency concerns while at the same time requiring their husbands to pay the cost of the reform. In short, this alternative proposal would ensure that high-income families pay high tax burdens without unfairly penalizing all workers with inelastic labor supphies.

More problems will develop, however, once McCaffery's proposal is reconstructed to account for realistic assumptions regarding a taxpayer's ability to pay. Economists, for example, do not umiversally accept one of the central underlying premises of progressive taxation-the behef that money has a decreasing marginal utility of income. ${ }^{31}$ Those who do not accept this description of the value of money are not likely to accept a tax rate structure that assigns low tax rates to low-income men and women who have inelastic labor supply curves. ${ }^{32}$ Economists who do accept this premise will nevertheless debate the difficult questions associated with the design of the rate structure, a problem that necessarily calls for value judgments. A utilitarian, for example, will advocate a system that looks very different from that advocated by a Rawlsian..$^{33}$ The point is that tax reform based on efficiency theory does not eliminate controversy and debate among economists. Optimal taxation may provide a useful starting point, but it does not solve the puzzle of devising a fair and efficient tax pohicy. Indeed, some economists argne that the optimal system of taxation is an ideal that cannot be achieved in practice because of the difficulty of discovering the elasticity curves along with the danger of basing taxation on erroneous data. $^{34}$

${ }^{31}$ Rosen, Public Finance at 164 (cited in note 18) (suggesting that marginal utility of income may be constant at all levels). See also Staudt, 50 Vand L Rev at 942-43 (cited in note 17) (noting that economists have questioned the validity of this assumption given the difficulty of interpersonal comparisons).

${ }^{32}$ See Rosen, Public Finance at 164 (cited in note 18) (noting that redistribution policies will not improve social welfare unless decreasing marginal utility of income theory liolds).

${ }^{33}$ See Bankman and Griffith, $75 \mathrm{Cal} \mathrm{L} \mathrm{Rev} \mathrm{at} \mathrm{1959-60} \mathrm{(cited} \mathrm{in} \mathrm{note} \mathrm{25)} \mathrm{(noting} \mathrm{the}$ potential differences in an income tax scheme devised by a utilitarian and a Rawlsian). For a discussion of various political theories, including utilitarianism and Rawlsianism, see Staudt, 50 Vand L Rov at 933-57 (cited in note 17).

* See, for example, Richard A. Musgrave and Peggy B. Musgrave, Public Finance in Theory and Practice 293 (McGraw-Hill 1989). 


\section{B. Feminists' Objections}

In writing Taxing Women, McCaffery provides the first indepth exploration of differential tax rates as a means for promoting women's market equality. The advantages of the proposal, from a feminist perspective, revolve around the fact that it recognizes important differences in men's and women's labor supphes. Yet it is precisely this feature of the proposal that will lead feminists to object to it. Moreover, as I discuss in the next Part, this feature is likely to limit, if not eliminate, any potential for agreement between economic and feminist theorists on pohcy outcomes.

Feminists who advocate equal treatment of men and women, for example, will object to any legislative pohicy that imposes differential treatment on men and women under the theory that sex bears no relationship to one's ability to perform or to contribute to society. ${ }^{35}$ These feminists argue that men and women are substantially similar and thus are entitled to similar treatment under the law. Indeed, preferential treatment is not only unnecessary, but it may even solidify and exaggerate the significance of the biological differences that have historically been central to the oppression of women..$^{36}$ As tax theorists have pointed out, formal equality theorists are likely to object to McCaffery's proposal. ${ }^{37}$

Of course, McCaffery might argue that optimal tax theory also mandates equal treatment of women and men, in the sense that both would be subject to tax burdens that unpose similar welfare losses. Indeed, McCaffery proposes that Congress use sex-neutral language in devising the differential tax burdens on men and women. Yet, as McCaffery acknowledges, even if Congress imposes a lower tax on the "secondary wage-earners" rather than on married women in particnlar, it is clear that women and not men will reap the benefits of the lower $\operatorname{tax}(p 21)$. Moreover, theorists attempting to disguise differential treatment of men and women miss the strategy underlying formal equality. As a strategic matter, formal equality feminists object to differential treatment of any kind between men and women on the theory that it works to sanction discriminatory treatinent that ultimately harms women. Preferential treatment has a poten-

${ }^{35}$ See, for example, Sylvia A. Law, Rethinking Sex and the Constitution, $132 \mathrm{U}$ Pa L Rev 955, 963-69 (1984) (discussing "assimilationist" views of sex equality).

${ }^{35}$ See id at 1007-13. See also Kathryn Abrams, Title VII and the Complex Female Subject, 92 Mich L Rev 2479, 2480 (1994) (distinguishing "sameness feminism" froun "difference feminism").

${ }^{3}$ See Alstott, 96 Colum L Rev at 2034 (cited in note 4). 
tially negative symbolic impact on women because it suggests that women are incapable of achieving success without assistance-a view that perpetuates the notion that women are fragile, incompetent, and powerless, thereby needing the protection of men and the state. Constraining the lhand of the state and eliminating all possible violations of this precept (which is strikingly similar to the principle of horizontal fairness) arguably serve women far better over time. In short, formal equality theorists would object to McCaffery's proposal because it calls for lower tax rates on married women than on men and single women, preferential treatment that can only impose lharm in the long run. ${ }^{38}$

Formal equality feminism is, of course, not universally accepted. A number of feminist theorists have criticized it sharply for advocating policies that essentially require women to live and work under laws designed by and for men. For instance, formal equality in the workplace would require men and women to work the same hours to achieve the same level of success, despite the fact that women often undertake childbearing and childrearing responsibilities in the home. ${ }^{39}$ Under the formal equality theory, therefore, women could only achieve "equality" in a workplace that is designed around the model of a single earner family, a model that neither recognizes women's work in the home nor gives men the flexibility to share in this labor. Formal equality, therefore, arguably fails to take account of women's unique circumstances, unintentionally sanctions oppressive relationships, and ultimately prevents women from achieving true economic, political, and social equality.

Initially, McCaffery's use of the optimal tax theory seems to satisfy this alternative branch of feminism, often called "dominance feminism." The optimal tax theory allows, indeed man-

${ }^{38}$ This does not mean that formal equality theorists would object to any proposal that lowers women's tax burdens. As McCaffery points out, inarried women currently suffer a greater tax burden than any other group due to the existence of the joint filing returns. This implies that formal equality theorists would support a policy of indepondent filing that would ensure that men and women are subject to identical tax rates at identical income levels. See, for example, Pamela B. Gann, Abandoning Marital Status as a Factor in Allocating Income Tax Burdens, 59 Tex L Rev 1, 32 (1980) (advocating the repoal of the joint return provisions). Efficiency theorists, on the other hand, would propose going much further than simply imposing identical tax burdens on men and women, given the fact that married women are more responsive te the wage rate. See, for example, Rosen, Public Finance at 332 (cited in noto 18) (noting that neutral taxation is not efficient).

3 See Abrams, 92 Mich $L$ Rov at 2480 (cited in note 36) (noting that "difference" feminists view discrimination as a failure to account for gender differences); Sara Ruddick, Maternal Thinking 42-44 (Beacen 1989) (discussing the historically different roles of mothers and fathers). 
dates, that Congress tailor legal reform to accommodate the differences in men's and women's labor supply elasticity, which in turn may be traced to the biological, psychological, and structural features that are unique to women's hves. ${ }^{40}$ Thus, rather than sanctioning the hierarchical relationships that currently exist, optimal tax theory has the potential to equalize them. Yet when McCaffery's argument is carefully examined, he is subject to the very criticisms leveled against the formal equality theorists. $\mathrm{He}$ fails to acknowledge that tax incentives do not eliminate the difficulties women face in entering the market. Employers, for example, have long resisted women's entry and advancement in the market given their assumption that women are uncommitted to waged labor. Moreover, even without these roadblocks women may be unable to work in hight of their childbearing and childrearing responsibilities.

Although McCaffery argues that his proposal is intended simply to offset the existing biases that working women suffer (i.e., to make the tax code truly neutral with regard to women's work in the home and in the market), the book reads as if McCaffery beheves women's choice to work in the home is a function of bad judgment or false consciousness. Indeed, he seems to ridicule legislators and women who suggest that mothers are forced into the workplace for economic reasons despite their true desire to stay home. McCaffery imphes that such arguments are merely clever rhetoric used to further oppress women in society ( $p 210){ }^{41}$ McCaffery argues, for example, that in promoting traditional family values, The Contract with America is "nothing more than a nightmare of patriarchy for many American women-a nightmare from which they cannot awake" (p 206). While this view does not detract from the important point that women suffer material costs when they perform unpaid labor in the home, it has distinct disadvantages from a third feminist viewpoint that seeks to acknowledge and value a caregiver's role in society. ${ }^{42}$

Throughout the book, McCaffery suggests that housework is marginalizing and oppressive while market labor is the only means for women to achieve economic independence and social

${ }^{40}$ See Staudt, 84 Georgetown L J at 1581-85 (cited in note 3) (discussing the various underlying reasons for women's movement in and out of the workplace).

"That McCaffery's proposal is designed only for its bebavioral effects on women's aggregate labor supply also is suggested by the fact that only married women who currently work in the home would be entitled to the tax reduction. If McCaffery were willing to allow all married women, not just those with elastic supply curves, to gain the benefit of the reduction, his proposal would be sure to lose the support of the economists.

12 See, for example, Robin West, Jurisprudence and Gender, 55 U Chi L Rev 1, 13-24 (1988) (discussing the work of cultural feminists). 
status (p 22). He fails to acknowledge, however, that economic vulnerability stems in large part from the fact that our society values market labor, but not unpaid domestic labor. Rather than proposing to value the work women traditionally do, McCaffery seeks to assimilate women into the market, the traditionally male sphere often perceived to be biased and unfriendly toward women. This type of reform perpetuates the notion that atomistic, market-oriented roles are more valuable to society than caring, nurturing, and relational roles-a view that is not universally shared. ${ }^{43}$ Moreover, the idea of pushing women into the workplace-along with reforms McCaffery has proposed elsewhere, such as the repeal of Title VII on the grounds that it has deleterious long-term effects on women ${ }^{44}$-will spark extensive criticism from feminists who are convinced that women suffer unfair biases in the workplace.

Despite its disadvantages, it might appear that McCaffery's proposal has the distinct advantage of encouraging men to undertake greater levels of household labor. If women move into the market, they share the responsibility of earning a wage, thereby potentially freeing men to perform a greater level of household labor. In fact, however, this role reversal does not take place. Sociological data indicate that women do not substitute market work for household responsibilities. ${ }^{45}$ Instead, women continue to be responsible for the bulk of the household labor even after moving into the waged labor force. As a result, focusing ouly upon women's market labor might increase the burden on women by encouraging women to work full-time in the waged labor market and full-time in the home. While this observation does not dissolve McCaffery's claim for lower marginal rates on married women, it suggests that the utility gains from his proposal will be offset by the utility losses that women incur due to the "double work load" that they are likely to suffer following a move into the waged labor market.

This discussion of McCaffery's work suggests that legal reformers generally and tax scholars in particular have ignored an

43 See Staudt, 84 Georgetown L J at 1616 (cited in noto 3). For an excellent discussion of this problem throughout the law, see Katharine Silbaugh, Turning Labor Into Love: Housework and the Law, $91 \mathrm{Nw} U \mathrm{~L}$ Rev 1 (1996).

" See Edward J. McCaffery, Slouching Toward Equality: Gender Discrimination, Market Efficiency, and Social Change, 103 Yale L J 595, 664-65 (1993) (advocating the repeal of regulatery provisions requiring equal pay).

45 See Shelton, Women, Men and Time at 65-66 (citod in noto 7) (noting the disparities in men's and women's labor time). See also Silbaugh, $91 \mathrm{Nw} U \mathrm{~L}$ Rev at 8-17 (citod in note 43) (discussing the phenomenon); Staudt, 84 Georgetown $L$ J at 1579-81 (cited in note 3) (same). 
important factor contributing to women's social, economic, and political marginalization. In a liberal society it is, of course, important for women to liave the option to move into the labor market. Yet sucl an opportunity may not be possible under any variant of feminist theory given the fact that the theorists do not address a central problem associated with the gendered division of labor. Formal equality feminism calls for equal treatment in the marketplace, dominance feminism calls for legal rules that recognize women's unique circumstances, and cultural feminism calls for society to value women's caretaking role in the home. None of the theories, however, provide a strategy for encouraging (or enabling) men to undertake a greater share of the louseliold chores. Until this is accomplisled, both men's and women's choices will be seriously circumscribed by the powerful social norms that place men in the market and women in the liome. Put differently, men and women may be temporarily able to transgress their traditional gendered roles, but in doing so they will suffer heavy costs that will, in turn, push them back into traditional roles.

\section{Disagreement Between Feminists and Economists}

The disagreements among feminists about the values underlying McCaffery's optimal tax system may translate into a further dispute with economists over empirical questions. In devising a rate scliedule that assures the desired belnavioral effect, Congress must determine the precise elasticity of married women's labor supply curves. Econometric studies, however, have produced a wide range of predictions with regard to women's labor supply elasticity. As McCaffery notes, the estimates have ranged from zero to well over one (pp 180-83), ${ }^{46}$ thereby predicting that women will either fail to respond to the rate cliange or be quite responsive. This discrepancy, of course, poses difficult problems for tax policyınakers who must cloose between the conflicting estimates. Choosing a number that overestimates women's elasticity, on the one hand, will produce a rate schedule that fails to accomplish McCaffery's behavioral goals. ${ }^{47}$ On the other hand, choosing an elasticity number that underestimates

${ }^{46}$ See also Bankman and Griffith, $75 \mathrm{Cal} \mathrm{L} \mathrm{Rev} \mathrm{at} \mathrm{1922-23} \mathrm{\&} \mathrm{nn} \mathrm{67-69,} 72$ (cited in note 25) (describing various approaches for estimating the elasticity of waged labor and citing to over thirty different studies).

${ }^{47}$ See Alstott, 96 Colum $L$ Rev at 2020 (cited in note 4). Alstott also points out that even if women respond te the changes in the tax structure, it is difficult to predict the manner in which they will respond. Id at 2036 (noting that different proposals encouraging market work will have different effects). 
women's elasticity will encourage Congress to decrease significantly the rates on married women while increasing the rates on men and single women to make the policy revenue neutral. Yet the difference in projected revenue and actual revenue could be huge if the latter group is priced out of the waged labor market due to the tax increase. ${ }^{48}$

Moreover, the pohicy choice will be comphicated by the fact that theorists might seek to use the econometric studies that best advance their underlying theory of fairness and gender justice. Although the manner in which feminist and economic theorists will align themselves in tax pohcy debates is difficult, if not impossible, to predict, it is easy to imagine certain coalitions. Those who seek to avoid giving a tax reduction to women, for example, are likely to defer to econometric studies suggesting that women are highly responsive to changes in the wage rate. This is true because the more women are responsive to the tax rates, the less Congress must reduce the tax burden to achieve its behavioral goal. Economists who argne that women's choices are highly responsive (or distorted) by taxation can be called "elasticity pessimists," given the fact that distortion leads to overall welfare losses. ${ }^{49}$ At the same time, theorists who seek to afford women preferential treatment are likely to defer to studies suggesting that women's choices are not highly distorted by changes in the tax code. In other words, these theorists would argne that Congress could only achieve its goal of encouraging women into the market with a siginficant tax reduction. Economists finding the latter might be called "elasticity optimists."50

It is easy to see that a large collection of feminists will be elasticity pessimists. Formal equality feminists will argue women should be subject to identical tax rates rather than lower rates than men. Feminists who seek legal reform reflecting the value of household labor also will object to tax reform that appears to value market labor over unpaid labor in the home. Yet dominance feminists will most likely support the elasticity opti-

${ }^{4}$ See John D. Jackson and Richard P. Saba, Some Limits on Taxing Sin: Cigarette Taxation and Health Care Finance, 63 S Econ J 761, 762-64 (1997) (noting that economists dispute the level to which Congress can raise taxes on cigarettes before reaching the point at which smokers will be priced out of the market).

Stiglitz, Economics of the Public Sector at 481 (cited in note 29).

so Id. A similar problem is found in the economists' debate over progressivity. Theorists who support progressive taxation tend to argue that the cost of reducing inequality is smaller than the costs perceived by those who argue against progressivity. This inconsistency occurs due to the underlying disagreements about the data reflecting the elasticities of individual behavior. Those who beheve that welfare losses are small are "elasticity optimists" while those who believe that distortions caused by taxation are large are often referred to as "elasticity pessimists." Id. 
mists. Indeed, given the wide range of predictions with regard to women's elasticity, even McCaffery may support the elasticity optimists to ensure his market-oriented behavioral goals are achieved. ${ }^{51}$ In short, until economists reach consensus on the precise elasticity of women's labor, there is room for significant disagreement among various strands of feminism, each group pointing to econometric studies supporting the underlying values it seeks to promote.

Therefore, McCaffery's suggestion that both feminists and economists will support the use of optimal tax theory is overstated. Economists themselves have not reached agreement on the fairness debate implicated by use of the theory. Moreover, feminist theorists are unlikely to universally support tax reform that awards a tax break to married women in order to encourage them into the market. In sliort, the most that can be said about McCaffery's proposal is that some economists and some feminists will support it.

The next Part turns to the implementation problems that exist with or without the successful coalition of feminists and economists.

\section{THE POLITICS OF REFORM}

Even if McCaffery's proposal were to garner the universal support of feminists and economists, the political problems associated with implementation would be difficult, if not impossible, to overcome. In failing to discuss these problems, McCaffery implies that upon discovering the inequities and inefficiencies contained in the existing tax code, Congress immediately will seek to remedy these flaws. ${ }^{52}$ McCaffery's view reflects the pubhic interest theory of pohtics-a view of pohtical decisionmaking that assumes legislators are altruistic and public-spirited enough to advocate and support legislation that (arguably) advances the interests of society as a whole. ${ }^{53}$

McCaffery, of course, is not alone in recognizing that the government can, in theory, play a role in promoting market effi-

${ }^{51}$ See Alstott, 96 Colum L Rev at 2033-42 (cited in note 4) (exploring McCaffery's market-oriented claims in particular); Staudt, 84 Georgetown L J at 1572-73, 1599-1618 (cited in note 3) (exploring and critiquing the market-oriented feminist scholars).

${ }^{52}$ McCaffery does, however, puzzle over the fact that politicians follow efficiency norms in some situations, but often do not in situations in which following the norns would advance the interests of women (pp 177, 190, 193, 202, 215, 225).

${ }^{53}$ For an excellent discussion of this view, see Daniel Shaviro, Beyond Public Choice and Public Interest: $A$ Study of the Legislative Process as Illustrated by Tax Legislation in the 1980s, 139 U Pa L Rev 1, 31-64 (1990). See also Nancy C. Staudt, Fiscal Constitutionalism 13 (unpubhished manuscript on file with U Chi L Rev). 
ciency as well as social justice. Indeed, economists since the framing of the Constitution have proposed using the government as a means of ensuring the growth and stability of the market economy, and a number of theorists have sought to use the tax code as a means of promoting distributional justice. Yet the school of thought that assumes government actors are willing and able to rise above their own self-interest for the interest of the public at large has been sharply criticized. Critics of the public interest theory argue that the realities of the existing political institutions make it almost impossible to implement a pohicy that would maximize social welfare under any theory of fairness or efficiency. While these critics come from many directions, I will focus specifically on the problems associated with two schools of thought: the special interest theory of pohtics and the expressive theory of politics.

Likely to be the major skeptics of McCaffery's public interest assumption are the public choice theorists, who argue that the legislative process works much like the private market, where special interest groups and voters form the demand side and the legislature forms the supply side. ${ }^{54}$ Although there are many branches of and insights to public choice theory, its major implication is that "legislation transfers wealth from society as a whole to discrete, well-organized groups that enjoy superior access te the political process and that government will enact laws that reduce societal wealth and economic efficiency in order to benefit these economic groups. ${ }^{n 55}$ Collective action problems explain why the wealth transfers tend to be enjoyed by narrow special interest groups, as the public choice theorists predict. Congressional members have an incentive to award narrow tax benefits as a means of obtaining contributions because the contributions, in turn, work to ensure their reelection. At the same time, the public at large is unable to monitor the political system and thus is unable to identify inefficient transfers that the public funds through higher taxes. Indeed, rational individuals will have little incentive to inform themselves about the nature of tax legislation given the fact that the personal cost of such legislation is often lower than the cost of acquiring the information about its inequalities and inefficiencies. Moreover, even if the costs of acquiring information about tax legislation were relatively low

${ }^{\text {st }}$ See William N. Eskridge, Jr., Politics without Romance: Implication of Public Choice Theory for Statutory Interpretation, 74 Va L Rev 275, 285 (1988) (providing a thorough explanation of public choice theorists' views on the market for legislation).

ss Jonathan R. Macey, Promoting Public-Regarding Legislation Through Statutory Interpretation: An Interest Group Model, 86 Colum L Rev 223, 230 (1986). 
compared to the costs of the laws' effects, the price of organizing an effective political coalition to oppose the policy is often so high that expending the resources necessary to understand the economic effects of the law remains irrational. ${ }^{56}$

McCaffery might argue that the pohtical struggles around the family tax rules do not conform to the special interest theory of politics. Althouglh he provides an account of a political struggle in which men systematically win while working women invariably lose, there is no evidence that men have organized into a powerful special interest group. Indeed, millions of working men hardly can be characterized as a well-organized interest group, successfully lobbying Congress for tax benefits. Unlike the typical narrow, self-interested group seeking narrowly tailored legislation, men on the whole appear to be just as diffuse and unorganized as the public at large.

At the same time, however, Taxing Women suggests that men as a whole have not benefited from the family tax rules. Instead, the beneficiaries liave been a fairly narrow sector of this group, principally working men with stay-at-home spouses. Moreover, as McCaffery points out, this group of elite men has participated in the political process, successfully advancing their own interests, as evidenced by the storm of protest over the 1941 joint return proposal ( $p$ 50). ${ }^{57}$ But even here, this group does not function in the manner that interest group theory would predict. Rather than making monetary contributions for legislation that advances their interest, McCaffery's work indicates that this group expressed its disapproval of the 1941 proposal and won support for the 1948 proposal largely througl writing newspaper articles and editorial pieces ( $p$ 50). While Congress does not ignore this form of pohtical action, special interest theory holds that it is campaigu contributions that most effectively capture legislators' attention. Thus, special interest theory cannot explani fully the development of the family tax rules. To understand the story that McCaffery recounts as well as the problems that his reform proposal will face, we must look to the literature exploring the expressive function and symbohic manipulation of politics.

\footnotetext{
${ }^{56}$ See Michael A. Fitts, Can Ignorance Be Bliss? Imperfect Information as a Positive Influence in Political Institutions, 88 Mich L Rev 917, 926-28 (1990) (noting that it is often irrational for the unorganized and diffuse pubhic to spend time and energy uncovering the economic effects of legislation); Jonathan R. Macey, Competing Economic Views of the Constitution, 56 Geo Wash L Rev 50, 77 (1987) (arguing that, as a general matter, citizens bave hittle incentive to inform themselves of the costs of ordinary statutes).

${ }^{57}$ See notes $2-4$ and accompanying text.
} 
Daniel Shaviro has provided the best explanation in the legal literature of the symbolic manipulation of tax pohtics. He notes that legislators' goal of reelection leads them not only to cultivate well-organized special interest groups, but also to propose and adopt legislation that has symbolic meaning to the general pubhic. ${ }^{58}$ Under this view, legislators are less interested in the substance of proposed legislation or its actual impact on society; ratler, they are focused on how the legislation will affect their reputations and chances for reelection. ${ }^{59}$ Voters, who are rationally ignorant about the substance of proposed legal reform, often are swayed by the emotional and symbolic message contained in legislation. The important implication of the theory of symbolic politics is that the public is willing to accept legal rules and policies that appear te decrease aggregate welfare if the law expresses a certain ideological and moral viewpoint.$^{60}$ In short, the expressive function of the law is often more important than the economic benefits associated witl it.

The problem with implementing McCaffery's proposal, therefore, lies with the fact that legislators and voters often act in an economically irrational manner. Despite the potential welfare gains available to society througl the use of optimal tax theory, Congress and the public at large might resist McCaffery's proposed reform in light of its expressive content. As McCaffery notes througlout the book, theorists and pohicymakers have used the federal income tax system as a symbol of the morality associated with traditional family values. Tax benefits for traditional married couples, it is argued, ensure that this particular family structure survives and flourishes, thereby advancing the interests of society in general. Stanley Surrey, for example, noted that the 1948 joint return provisions alleviated women of their onerous business responsibilities, enabling them to return to the noble and loving "pursuit of homemaking" ( $p$ 57). ${ }^{61}$ The Social Secu-

Shaviro, 139 U Pa L Rev at 7-8 (cited in note 53); Daniel Shaviro, Do Deficits Matter? 274-78 (Chicago 1997).

so See Shaviro, $139 \mathrm{U} \mathrm{Pa} \mathrm{L}$ Rev at 83-86 (cited in note 53) (analyzing the benefits-beyoud its pohicy goals $\rightarrow$ of making legislation).

' See id at 77-80 (noting voters' willingness to forego self-interest and voto along symbolic lines). See also Cass R. Sunstein, On the Expressive Function of Law, $144 \mathrm{U}$ Pa $L$ Rev 2021 (1996) (discussing the effect of law on social meaning); Dan M. Kahan, What Do Alternative Sanctions Mean?, 63 U Chi L Rev 591 (1996) (exploring the symbolic meaning of punishment); Lawrence Lessig, The Regulation of Social Meaning, $62 \mathrm{U}$ Chi $\mathrm{L}$ Rev 943 (1995) (exploring the expressive function of law generally); Richard H. Pildes, The Unintended Cultural Consequences of Public Policy, 89 Mich L Rev 936 (1991) (analyzing the effect of pubhic policy on social understandings).

${ }^{61}$ See Stanley S. Surrey, Federal Taxation of the Family-The Revenue Act of 1948, 61 Harv L Rev 1097, 1111 (1948). 
rity and fringe benefit provisions also enable women to enjoy work-related benefits without engaging in the market work that is assumed to cause the deterioration of the modern male-headed nuclear family (pp 89-136). Similarly, the nontaxation of imputed income is widely accepted as giving caretakers a "tax benefit" for the valued services they provide to the home (pp 120-22). That pohicymakers continue to use the tax code as a means of expressing reverence for women's household labor is evident in The Contract with America, which suggests that through child credits a woman will be able to provide better care for her home and her family, thereby saving the marriage and protecting her children from the consumerist culture that values "Nintendos and Nikes" rather than basic family structures ( $p 208$ ).

Within this cultural landscape, McCaffery's proposal to provide women with incentives to substitute market work for household labor is likely to be viewed as anti-family tax relief. Indeed, even if pohticians recoginze the value of women's market labor to the overall economy, it could be professional suicide to advocate a policy that goes so far as to reduce the tax rate on women below that imposed upon men. Most Americans believe that women's work is not only discretionary but that given the scarcity of jobs and the importance of family, women have a duty not to work ( $p$ p 22, 77). A tax law that provided incentives for women to work in the waged labor force would be viewed widely with suspicion and contempt. As Representative Pete Stark has acknowledged, congressional representatives will "do whatever is politically popular" rather than economically sound (p 77). ${ }^{62}$

Of course, a skilled pohtical entrepreneur might cast McCaffery's proposal in a manner that expresses a social meaning acceptable to the pubhic at large. For example, McCaffery specifically focuses on the burden that married women suffer and thus his proposal might be characterized as "pro-marriage" tax reform. The recent attention given to the so-called "marriage penalty" and the bipartisan support for its elimination suggest that this maneuver could be politically successful.

The marriage penalty is the added burden that working couples suffer upon getting married. Reform proposals intended to address the marriage penalty give tax benefits to dual earner couples, thereby operating as an incentive to both men's and women's market labor. Yet, as the label suggests, the reform is

${ }^{62}$ Tax Treatment of Married, Head of Household, and Single Taxpayers, Hearings before the Committee on Ways and Means, 96th Cong, 2d Sess 218 (1980) (remarks of Representative Pete Stark). 
widely viewed as an incentive to marriage, not to market work. Similarly, McCaffery's proposal might gain support if characterized as "pro-marriage" tax reform rather than reform that promotes economic efficiency and gender justice. Although this label misses the nuance of McCaffery's analysis, the public generally is less interested in the technical details of tax reform or the precise nature of the problem to be remedied. What is important is the perceived social meaning of the legislation; the public responds to pohtical symbols.

Pohitical rhetoric, however, does not eliminate the possibility that the details of McCaffery's tax reform proposal will be revealed. In an effort to incite opposition, opponents of the proposal are likely to highlight the fact that McCaffery hopes to reduce the rate on married women to below that of single men and women. This implies that he believes married women should be in the labor market, a view that is not universally shared. Indeed, working women are often viewed as a threat to the survival of the family. ${ }^{63}$ Thus, even if the public is swayed imitially, popular opinion could quickly change with enormous negative repercussions for the legislators who support the proposed reform. ${ }^{64}$ Understanding this threat, cautious legislators who beheve the public can and will be incited against the proposed legislation will adjust their position on the issue to correspond more directly with public opinion over the long run. ${ }^{65}$

Moreover, if, as in the past, the small group of ehte men with stay-at-home spouses object te McCaffery's proposed reform, the proposal is likely to meet defeat. Murray Edelman's classic text, The Symbolic Uses of Politics, demonstrates how the public's taste for abstract symbols can further the interest of narrow interest groups. ${ }^{66}$ Edelman argues that while the general public is captivated and enthralled by the emotional content of the symbol, the smaller, organized groups keep an eye on the substance of legislation. Indeed, the latter assist in the manipulation of symbols in order to win the widespread support for policies and programs that favor their own material interests. ${ }^{67}$ This theory predicts the pattern that McCaffery discovers in Taxing Women. While the traditional single earner families endlessly win tax

* See, for example, p 166 (noting the controversial nature of his proposal and the number of poople who have commented to him that "traditional families with stay-athome wives [are] good for society, for children, for men, even for women").

che R. Douglas Arnold, The Logic of Congressional Action 68 (Yale 1990).

${ }^{\infty}$ See id at 70 .

* Murray Edelman, The Symbolic Uses of Politics 22-27 (Illinois 1964).

"7 Id at 36-40. See also Shaviro, $139 \mathrm{U} \mathrm{Pa} \mathrm{L} \mathrm{Rev} \mathrm{at} 48$ (cited in note 53) (discussing Edelman's work in the tax context). 
benefits, dual earning couples (and working wives in particular) suffer the costs. Symbohic politics, therefore, tends to produce legislation that harms the economic interests of the very groups that support it-a point that McCaffery implies throughout the book witl regard to women's decisions to work in the home. ${ }^{68}$

Of course, the legal reform McCaffery proposes could be worthwhile precisely because of the message it conveys about the outdated social norms that have been codified in the tax laws. Indeed, legal reform might be necessary to change the norms given the collective action problem associated witl changing social mores in the private market context. A number of structural barriers continue to exist in the market due to employers' assumption that women are uncommitted to waged work given their desire to work in the home and to care for children. ${ }^{69}$ These obstacles, in turn, may cause women to lower their aspiration and commitment to the waged labor force, thereby reinforcing the very stereotype that made it impossible to achieve success in the first place. ${ }^{70}$ Women, of course, are powerless to solve this problem alone, and employers will not be easily convinced that women are willing to abandon work in the home for market labor (pp 242-43). Accordingly, legal reform that not only symbohzes the importance of women's work, but also makes that work possible, is particularly important for changing social norms. ${ }^{71}$

The problem is that Congress will resist adopting legislation that works to change the norm given the existence of the norm itself. Legislators, endlessly worried about reelection, are far more likely to adopt legislation that reinforces the norm than legislation that challenges it. In short, the symbolic use of the tax law imphes that there are serious limits to the type of legal reform suggested by McCaffery and other hberal legal reformers. McCaffery's argument clearly identifies the fairness and efficiency problems associated with the existing tax structure. But lie ignores the deeply entrenched views that have legitimated the

${ }^{68}$ As Daniel Shaviro notes, however, if people want the legislation they get, then it is questionable te say they are harmed by it. Their economic interests may certainly be harmed, but the utility losses from such costs may be lower than the utility gains fron the expressive content of the law. Shaviro, $139 \mathrm{U} \mathrm{Pa} \mathrm{L} \mathrm{Rev} \mathrm{at} \mathrm{48-49} \mathrm{(cited} \mathrm{in} \mathrm{note} \mathrm{53).}$

${ }^{\infty}$ See Vicki Schultz, Telling Stories About Women and Work: Judicial Interpretations of Sex Segregation in the Workplace in Title VII Cases Raising the Lack of Interest Argument, 103 Harv L Rev 1750, 1814-16 (1990) (noting the need to analyze the role that organizational structure plays in shaping work preferences).

${ }^{70}$ See Resaheth Moss Kanter, The Impact of Hierarchical Structures on the Work Behavior of Women and Men, in Rachel Kahn-Hut, Arlene Kaplan Daniels, and Richard Colvard, eds, Women and Work: Problems and Perspectives 234, 235 (Oxford 1982).

"See Cass R. Sunstein, Social Norms and Social Roles, 96 Colum L Rev 903, 923 (1996) (exploring the way in which law can help to constitute and redefine roles). 
system in the first place. Legislators and society in general seem largely uninterested in the possibility of equalizing the market options between men and women. Indeed, the evidence suggests just the opposite.

\section{CONCLUSION}

Taxing Women provides a detailed and nuanced account of the gendered nature of tax policy. In exploring this bias, Edward McCaffery argues that Congress can simultaneously promote gender justice and econormic efficiency through the reduction of married women's federal tax rates. Althougl many view this as an argument for providing an unfair economic advantage to women, McCaffery powerfully argues that maintaining the status quo simply enables men to reap the benefits of a windfall they were given decades ago ( $p$ 271). While McCaffery's work is ingenious in a number of ways, many econoumc and feminist theorists will object to his proposal. Moreover, he fails to recognize the importance of ideology, morality, and social norms in the context of political reform. Iguoring the expressive content and the symbolic manipulation of the law disregards a key factor in achieving pohtical change generally and tax reform in particular. Accordingly, McCaffery's book suggests that feminists, economists, and tax policy theorists must move beyond the task of identifying tax injustices and economic inefficiencies to a research agenda that explores the difficulties of implementing political cliange in a society that resists it. 


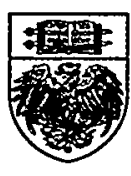

HeinOnline -- 65 U. Chi. L. Rev. 6841998 